\title{
Polymorphisms in Inflammatory and Immune Response Genes Associated with Cerebral Cavernous Malformation Type 1 Severity
}

\author{
Hélène Choquet $^{a} \quad$ Ludmila Pawlikowska $^{a}$ b Jeffrey Nelson ${ }^{a}$ \\ Charles E. McCulloch ${ }^{c}$ Amy Akers ${ }^{d}$ Beth Baca ${ }^{e}$ Yasir Khan ${ }^{e}$ Blaine Hart ${ }^{f}$ \\ Leslie Morrison $^{\mathrm{e}, \mathrm{g}}$ Helen Kim ${ }^{\mathrm{a}-\mathrm{c}}$ on behalf of the Brain Vascular Malformation
}

Consortium (BVMC) Study

${ }^{a}$ Center for Cerebrovascular Research, Department of Anesthesia and Perioperative Care, ${ }^{b}$ Institute for Human Genetics, 'Department of Epidemiology and Biostatistics, University of California, San Francisco, Calif., ${ }^{\mathrm{d}}$ Angioma Alliance, Durham, N.C., and Departments of ${ }^{\mathrm{e}}$ Neurology, ${ }^{\mathrm{f}}$ Radiology, and ${ }^{\mathrm{g}}$ Pediatrics, University of New Mexico, Albuquerque, N. Mex., USA

\section{Key Words}

Cerebral cavernous malformation - CCM1 disease severity - Intracerebral hemorrhage · Brain lesion count . Inflammation and immune response modifier genes

\begin{abstract}
Background: Familial cerebral cavernous malformation type 1 (CCM1) is an autosomal dominant disease caused by mutations in the Krev Interaction Trapped 1 (KRIT1/CCM1) gene, and characterized by multiple brain lesions that often result in intracerebral hemorrhage $(\mathrm{ICH})$, seizures, and neurological deficits. Carriers of the same genetic mutation can present with variable symptoms and severity of disease, suggesting the influence of modifier factors. Evidence is emerging that inflammation and immune response play a role in the pathogenesis of CCM. The purpose of this study was to investigate whether common variants in inflammatory and immune response genes influence the severity of familial CCM1 disease, as manifested by ICH and greater brain lesion count. Methods: Hispanic CCM1 patients $(n=188)$ harboring the founder Q455X 'common Hispanic mutation' (CHM) in the KRIT1 gene were analyzed at baseline. Participants were enrolled be-
\end{abstract}

\section{KARGER}

E-Mail karger@karger.com

www.karger.com/ced tween June 2010 and March 2014 either through the Brain Vascular Malformation Consortium (BVMC) study or through the Angioma Alliance organization. Clinical assessment and cerebral susceptibility-weighted magnetic resonance imaging were performed to determine $\mathrm{ICH}$ as well as total and large ( $\geq 5 \mathrm{~mm}$ in diameter) lesion counts. Samples were genotyped on the Affymetrix Axiom Genome-Wide LAT1 Human Array. We analyzed 830 variants in 56 inflammatory and immune response genes for association with $\mathrm{ICH}$ and residuals of logtransformed total or large lesion count adjusted for age at enrollment and gender. Variants were analyzed individually or grouped by sub-pathways or whole pathways. Results: At baseline, $30.3 \%$ of CCM1-CHM subjects had ICH, with a mean \pm standard deviation (SD) of $60.1 \pm 115.0$ (range $0-713$ ) for total lesions and $4.9 \pm 8.7$ (range $0-104$ ) for large lesions. The heritability estimates explained by all autosomal variants were 0.20 ( $\mathrm{SE}=0.31), 0.81(\mathrm{SE}=0.17$ ), and $0.48(\mathrm{SE}=0.19)$, for $\mathrm{ICH}$, total lesion count, and large lesion count, respectively. TGFBR2 rs9823731 was significantly associated with ICH as well as with the total and large lesion counts $(p \leq 0.017)$. Further, IL-4 rs9327638, CD14 rs778588, IL-6R rs 114660934 and MSR1 rs62489577 were associated with two markers of disease severity. Finally, the whole pathway was associated with
(C) 2014 S. Karger AG, Basel

1015-9770/14/0386-0433\$39.50/0 
total lesion count $(\mathrm{p}=0.005)$ with $T L R-4 \mathrm{rs} 10759930, C D 14$ rs778588, IL-6R rs114660934 and IGH rs57767447 mainly bearing this association. Eicosanoid signaling, extracellular pattern recognition, and immune response sub-pathways were also associated with the total lesion count. Conclusions: These results suggest that polymorphisms in inflammatory and immune response pathways contribute to variability in CCM1 disease severity and might be used as predictors of disease severity. In particular, TGFBR2 rs9823731 was associated with all three markers of CCM1 disease severity tested, suggesting that TGFBR2 might be a key participant in the mechanism underlying CCM1 disease severity and phenotype variability. However, further longitudinal studies in larger sample sizes are needed to confirm these findings.

(c) 2014 S. Karger AG, Basel

\section{Introduction}

Familial cerebral cavernous malformations (CCM) are characterized by multiple lesions consisting of thinwalled leaky capillaries, which can lead to intracerebral hemorrhage (ICH), seizures, and neurological deficits. Familial CCM type 1 (CCM1) is an autosomal dominant disease caused by mutations in the Krev Interaction Trapped 1 (KRIT1) gene. Familial CCM1 patients with the same genetic mutation can present with variable symptoms and disease severity even among members of the same family [1-3]. The factors underlying this variability are poorly understood, but may include genetic modifiers or epidemiological factors, for example, obesity or hypertension [1].

Several studies have implicated dysregulated inflammatory and immune responses in vascular malformation pathogenesis, including CCM [4-7]. Inflammatory and immune cells such as monocytes, macrophages, $\mathrm{B}$ and $\mathrm{T}$ cells, are present in human CCM lesions, particularly in response to acute bleeding [6-8], as well as in mouse models of CCM $[9,10]$. Further, gene expression arrays have revealed a number of immunoglobulin genes and markers of immune cells with altered expression in human CCM tissue $[4,11]$. Common functional polymorphisms in inflammatory cytokine genes have been associated with ICH in other brain vascular diseases, including arteriovenous malformations (AVM) [12-16] and intracranial aneurysms [17].

Therefore, we hypothesized that common genetic variation in inflammatory and immune response genes would influence disease severity in CCM1, as manifested by an increased risk of ICH or greater total or large lesion count, in a cohort of Hispanic CCM1 subjects.

\section{Methods}

\section{Study Population}

The study sample comprised 188 CCM1 subjects, all confirmed carriers of the Common Hispanic Mutation (CHM) in KRIT1 (Q455X, rs267607203) by genetic testing as previously described [1], and with both genotype and phenotype data available. Subjects were recruited from two sources: (a) 182 participants enrolled between June 2010 and March 2014 through the Brain Vascular Malformation Consortium (BVMC) study at the University of New Mexico (UNM); and (b) 6 participants enrolled through the Angioma Alliance patient advocacy group's DNA and Tissue Bank study. All data, including DNA, imaging, and clinical data, were de-identified prior to analysis. The study was approved by the local institutional review boards at UNM, University of California, San Francisco (UCSF), and Quorum IRB (Angioma Alliance), and by the National Institutes of Neurological Disorders and Stroke (NINDS). Written informed consent was obtained from all participants.

\section{Phenotyping}

Clinical assessment of each participant was conducted to obtain information on presenting symptoms leading to CCM diagnosis using standardized guidelines [18]. MRI was performed at study enrollment using a volume T1 acquisition (MPRAGE, 1-mm slice reconstruction) and axial TSE T2, T2 gradient recall, susceptibility-weighted, and FLAIR sequences. Lesion counting was based on concurrent evaluation of axial susceptibility-weighted imaging, which is a volume acquisition, with $1.5-\mathrm{mm}$ reconstructed images and axial T2 gradient echo, 3-mm images. Large lesions were defined as those with a maximum diameter of $5 \mathrm{~mm}$ or greater on TSE T2 images. CCM lesions less than $5 \mathrm{~mm}$ in size mostly represent hemosiderin-only signal. These were not additionally measured because the accuracy of measurements decreases as lesion size becomes smaller than slice thickness for T2-weighted images (around $5 \mathrm{~mm}$ ). Gradient-recall sequences did have thinner slice thickness but are unreliable for the measurement of size because of well-recognized susceptibility effects that result in 'blooming' in the apparent size. We analyzed three markers of CCM1 disease severity: history of $\mathrm{ICH}$, total lesion count, and large lesion count.

\section{Genotyping and Quality Control}

Blood or saliva samples were collected and genomic DNA was extracted using standard protocols. Blood samples collected for the BVMC study were sent to the NINDS Repository at the Coriell Institute for Medical Research for DNA extraction and cell line immortalization. Blood samples collected from Angioma Alliance were sent to PreventionGenetics (Marshfield, Wisc., USA) and saliva samples were sent directly to UCSF for DNA extraction. Samples were normalized, plated on two 96-well plates, and genotyped at the UCSF Genomics Core Facility using the Affymetrix Axiom ${ }^{\circledR}$ Genome-Wide LAT 1 (Axiom GW LAT) Human Array [19], which includes 817,810 single nucleotide polymorphisms (SNPs) and is optimized for genotyping Hispanic populations. The Affymetrix Genotyping Console (GTC) 4.1 Software package was used to generate quality control (QC) metrics and genotype calls. All samples had a genotyping call rate of $97 \%$ or greater, and the two Affymetrix Reference DNA controls were concordant. Genotype data were exported into PLINK software (v1.07) for further 
QC (sex check, Mendelian errors and cryptic relatedness) and data analysis. Neither sex discordance nor Mendelian errors were identified.

\section{Gene and Variant Selection}

We selected 56 candidate genes that encode proteins functioning in inflammatory or immune response pathways, and prioritizing genes previously reported for other brain vascular malformations or implicated in CCM lesion biology. Our candidate gene list includes: (1) inflammatory cytokines, as polymorphisms in notably $I L 1 A, I L 1 B, I L 1 R N$ and TNF genes have been previously reported associated with phenotypes of brain vascular diseases, including brain arteriovenous malformations or intracranial aneurysms [12$17,20]$; (2) transforming growth factor- $\beta$ (TGF- $\beta$ ) and related genes that inhibit TGF- $\beta$ signaling, reducing the number and size of lesions and vessel leakage in CCM1-deficient mice [10]; (3) genes that encode proteins expressed or secreted by inflammatory or immune cells (T cells, B cells, monocytes and macrophages) and other related genes coding for proteins involved in immune cell development (i.e., CD14, IFNG, IL5, IL6R, IL8, IL18, IL18R1,IL12A, IL12B, IL2, IL17A, IL23A, NFKB1, MIF, and MSR1) as inflammatory or immune cells are present in human CCM lesions $[4,6,11] ;(4)$ toll-like receptors genes (TLR1, TLR2, TLR3, TLR4, TLR5, TLR6, and TLR10) as well as $C O X-2$ and Selenoprotein genes as encoded proteins have been reported to be essential in the pathogenesis of cerebral ischemia and the pathologic progression of the disease [21-26]; (5) immunoglobulins and other related genes with altered expression in human CCM lesions (CD247, CD3G, CD68, CD200, GUSP11, HLA-DRB1, IGH, IGJ, IGL, LOC390714, MS4A1 and SDC1) $[4,11]$.These genes were classified into the following biological sub-pathways [27, 28]: (a) cytokine signaling; (b) eicosanoid signaling; (c) extracellular pattern recognition; (d) NFKB signaling; (e) selenoproteins; and (f) immune response (see online suppl. table 1; for all online suppl. material, see www.karger.com/doi/10.1159/000369200). Gene loci were defined as $\pm 5 \mathrm{~kb}$ upstream and downstream of the sequence using UCSC Genome Browser Assembly February 2009 (GRCh37/hg19). Genotypes for 1,700 SNPs on the Axiom GW LAT Human Array within the candidate loci were extracted. We excluded 257 SNPs for the following reasons: genotype call rate $<98 \%$, a minor allele frequency (MAF) $<1 \%$, or deviation from Hardy-Weinberg equilibrium ( $\mathrm{p}<$ 0.001 ). After removing 613 SNPs that were in high linkage disequilibrium $\left(\mathrm{r}^{2} \geq 0.8\right)$ using a 5-SNP sliding window approach in PLINK, 830 variants remained for association analysis. MAF of SNPs associated with CCM1 severity markers are reported in online supplementary table 2 and are compared with general populations from public databases: 1,000 Genomes global population (phase 1 genotype data from 1,094 worldwide individuals) and HapMap MEX (Mexican Ancestry in Los Angeles).

\section{Statistical Analysis}

Residuals of log-transformed total or large lesion count were obtained after adjustment for age at enrollment and gender $(\mathrm{R}$ $\mathrm{v} 2.10 .1$ software). To identify genotypes (assuming an additive genetic model, i.e., 0,1 , or 2 copies of the minor allele) associated with $\mathrm{ICH}$, we performed a DFAM family-based association test for disease traits (PLINK v1.07) to accommodate for different family structures, which uses a Cochran-Mantel-Haenszel test. To identify genotypes associated with residuals of log-total or large lesion count, we first performed linear regression analysis implemented in the QFAM family-based association test for quantitative traits

Inflammatory and Immune Response

Polymorphisms and CCM1 Severity
Table 1. Clinical characteristics of the 188 Hispanic CCM1-CHM subjects

\begin{tabular}{lc}
\hline Characteristics & \multicolumn{1}{l}{ Values } \\
\hline Male gender, $\mathrm{n}(\%)$ & $64(34.0)$ \\
Family size (affected members), $\mathrm{n}(\%)$ & $54(55.1)$ \\
$\quad 1$ member & $23(23.5)$ \\
2 members & $21(21.4)$ \\
$\quad 3-8$ members & \\
Age at enrollment, years & $39.0 \pm 19.5$ \\
$\quad$ Mean \pm SD & $6.6-84.9$ \\
$\quad$ Range & $57(30.3)$ \\
History of hemorrhage, $\mathrm{n}(\%)$ & \\
Total lesion count & $60.1 \pm 115.0$ \\
$\quad$ Mean \pm SD & $0-713$ \\
$\quad$ Range & \\
Large lesion count & $4.9 \pm 8.7$ \\
$\quad$ Mean \pm SD & $0-104$ \\
$\quad$ Range & \\
\hline
\end{tabular}

(PLINK v1.07), which uses between and within family permutation to account for differences in the family structure. $p$ values were generated using 100,000 permutations. Variants with $\mathrm{p}$ values $\leq 0.017$ ( $0.050 / 3$ markers of disease severity) in any outcome are reported. We also present more stringent multiple testing correction (Bonferroni adjustment for the number of variants tested within each candidate genes). SNP-based heritability estimates were obtained separately for $\mathrm{ICH}$, total lesion count and large lesion count using the GCTA software [29], which computes the phenotypic variance explained by all analyzed SNPs in the genome by restricted maximum likelihood achieved using expectation maximization (REML). For quality control purposes, we restricted the analysis to autosomal SNPs with genotype call rate $\geq 98 \%$, a MAF $\geq 1 \%$, and in Hardy-Weinberg equilibrium ( $\mathrm{p} \geq 0.001)$. As related individuals were present in our sample and this can bias heritability estimates from GCTA [30-33], we also estimated heritability using a family-based approach in SOLAR v7.2.5 software [34]. To analyze the whole set of SNPs together, or sets of SNPs grouped by sub-pathways, we used the set-based test in PLINK v1.07, which takes account of the LD between the SNPs and corrects $p$ values for the multiple SNPs tested within a set. Power calculations were performed using QUANTO software (http://hydra.usc.edu/gxe/). With 188 CCM1-CHM subjects, we have over $80 \%$ power to detect an odds ratio (OR) between 2.2 and 5.2 for $\mathrm{ICH}$ and a $13-63 \%$ difference in lesion count when the MAF varies between 0.05 and 0.50 .

\section{Results}

\section{Participant Characteristics}

Table 1 shows the descriptive statistics of the 188 CCM1-CHM subjects included in this study. The mean age at enrollment was $39.03 \pm 19.5$ years and the majority were female $(66.0 \%)$. In our sample, $30.3 \%$ of CCM1$\mathrm{CHM}$ subjects had a history of ICH. At baseline, the aver- 
Table 2. Heritability estimates of markers of CCM1 disease severity

\begin{tabular}{lllllll}
\hline & \multicolumn{2}{l}{ SNP-based analysis } & & \multicolumn{2}{l}{ Family-based approach } \\
\cline { 2 - 3 } & heritability estimate, \% (SE) & $\mathrm{p}$ & & heritability estimate, \% (SE) & $\mathrm{p}$ \\
\hline ICH & $20(31)$ & 0.30 & $21(38)$ & 0.28 \\
Total lesion count & $81(17)$ & $\mathbf{2} \times \mathbf{1 0}^{-\mathbf{6}}$ & $63(21)$ & $\mathbf{0 . 0 0 1 8}$ \\
Large lesion count & $48(19)$ & $\mathbf{0 . 0 0 4}$ & & $30(21)$ & 0.059 \\
\hline
\end{tabular}

Table 3. Genetic variants associated with $\mathrm{ICH}$

\begin{tabular}{|c|c|c|c|c|c|c|}
\hline Gene & SNP & $\begin{array}{l}\text { Minor } \\
\text { allele }\end{array}$ & MAF & $\chi^{2}$ & $\mathrm{p}$ & $\mathrm{p}^{*}$ \\
\hline \multicolumn{7}{|c|}{ Cytokine signaling } \\
\hline \multirow[t]{2}{*}{$I L 1 R N$} & rs315947 & $\mathrm{A}$ & 0.26 & 8.25 & 0.004 & 0.061 \\
\hline & rs928940 & G & 0.14 & 7.86 & 0.005 & 0.076 \\
\hline & rs9327638 & A & 0.20 & 7.09 & 0.008 & 0.18 \\
\hline \multirow[t]{2}{*}{ TGFBR2 } & rs17025785 & $\mathrm{C}$ & 0.42 & 9.03 & 0.003 & 0.12 \\
\hline & rs9823731 & $\mathrm{A}$ & 0.36 & 6.88 & 0.009 & 0.41 \\
\hline \multicolumn{7}{|c|}{ NFKB signaling } \\
\hline CHUK & rs4919435 & $\mathrm{T}$ & 0.07 & 5.73 & 0.017 & 0.13 \\
\hline \multicolumn{7}{|c|}{ Selenoproteins } \\
\hline SELS & rs4965815 & $\mathrm{T}$ & 0.06 & 6.90 & 0.009 & 0.069 \\
\hline \multicolumn{7}{|c|}{ Immune response } \\
\hline$C D 3 G$ & rs11216856 & $\mathrm{T}$ & 0.31 & 6.56 & 0.010 & 0.052 \\
\hline$I G H$ & rs55847330 & $\mathrm{T}$ & 0.14 & 6.70 & 0.010 & 0.68 \\
\hline \multirow[t]{4}{*}{$I G L$} & rs6002270 & $\mathrm{T}$ & 0.03 & 6.72 & 0.009 & 1.0 \\
\hline & rs10854762 & $\mathrm{A}$ & 0.22 & 6.52 & 0.011 & 1.0 \\
\hline & rs9622749 & G & 0.14 & 5.83 & 0.016 & 1.0 \\
\hline & rs5757039 & $\mathrm{T}$ & 0.10 & 5.76 & 0.016 & 1.0 \\
\hline
\end{tabular}

Table gives the Chi-squared $\left(\chi^{2}\right)$ from a Cochran-Mantel-Haesnzel test, and $\mathrm{p}$ values. $p$ values in bold are considered statistically significant $(\mathrm{p} \leq 0.017)$.

* p values adjusted for Bonferroni correction (for the number of variants tested within candidate genes).

age number of lesions observed was $60.1 \pm 115.1$ (range from 0 to 713 ) and the average number of large lesions was $4.9 \pm 8.7$ (range from 0 to 104).

\section{Estimation of Heritability}

SNP-based analysis resulted in a heritability estimate of $0.20(\mathrm{SE}=0.31), 0.81(\mathrm{SE}=0.17)$ and $0.48(\mathrm{SE}=0.19)$, for ICH, total lesion count and large lesion count, respectively. The family-based analysis, yielded similar heritability estimates (table 2).

\section{Association with $\mathrm{ICH}$}

We first evaluated whether common variants in inflammatory and immune response genes were associated with $\mathrm{ICH}$. We found that 7 variants in 5 inflammatory genes (IL-1RN, IL-4, TGFBR2, CHUK and SELS) and 6 variants in 3 immune response genes (CD3G, IGH and $I G L)$ were significantly associated with ICH $(\mathrm{p} \leq 0.017)$ (table 3). No association remained significant after adjusting for the number of variants tested within candidate genes (table 3).

\section{Association with Total and Large Lesion Counts}

We also evaluated whether common variants in inflammatory and immune response genes were associated with total and large lesion counts in CCM1-CHM subjects. Interestingly, the $I L-4$ rs9327638 and TGFBR2 rs9823731 polymorphisms reported above and associated with ICH were also significantly associated with total and/or large lesion counts, independent of age and gen- 
Table 4. Genetic variants associated with lesion counts

\begin{tabular}{|c|c|c|c|c|c|c|c|c|c|}
\hline Gene & SNP & $\begin{array}{l}\text { Minor } \\
\text { allele }\end{array}$ & MAF & \multicolumn{3}{|l|}{ Total lesion count } & \multicolumn{3}{|l|}{ Large lesion count } \\
\hline \multicolumn{10}{|c|}{ Cytokine signaling } \\
\hline \multirow[t]{2}{*}{ IL4 } & rs9327638 & A & 0.20 & $1.21(0.90-1.61)$ & 0.28 & 1.0 & $1.38(1.14-1.67)$ & 0.005 & 0.025 \\
\hline & rs194395 & $\mathrm{T}$ & 0.22 & $0.68(0.52-0.90)$ & 0.016 & 0.36 & $0.81(0.67-0.97)$ & 0.048 & 0.24 \\
\hline IL5 & rs10072700 & $\mathrm{C}$ & 0.20 & $1.45(1.11-1.90)$ & 0.017 & 0.58 & $1.15(0.95-1.38)$ & 0.20 & 1.0 \\
\hline IL18R1 & rs3732126 & $\mathrm{C}$ & 0.14 & $1.56(1.15-2.12)$ & 0.016 & 0.19 & $1.01(0.82-1.25)$ & 0.93 & 1.0 \\
\hline \multirow[t]{3}{*}{ TGFBR2 } & rs12491780 & $\mathrm{T}$ & 0.27 & $0.80(0.63-1.02)$ & 0.11 & 1.0 & $0.81(0.69-0.95)$ & 0.015 & 0.71 \\
\hline & rs11924422 & $\mathrm{C}$ & 0.36 & $1.41(1.13-1.76)$ & 0.007 & 0.32 & $1.21(1.05-1.41)$ & 0.023 & 1.0 \\
\hline & rs9823731 & A & 0.36 & $1.39(1.12-1.73)$ & 0.011 & 0.53 & $1.26(1.09-1.45)$ & 0.009 & 0.42 \\
\hline \multicolumn{10}{|c|}{ Eicosanoid signaling } \\
\hline TLR6 & rs73811240 & A & 0.17 & $0.69(0.53-0.89)$ & 0.015 & 0.16 & $0.86(0.72-1.02)$ & 0.13 & 1.0 \\
\hline \multicolumn{10}{|c|}{ Immune response } \\
\hline CD14 & rs778588 & $\mathrm{C}$ & 0.27 & $1.51(1.19-1.90)$ & 0.003 & 0.009 & $1.24(1.06-1.45)$ & 0.017 & 0.051 \\
\hline$C D 3 G$ & rs3181261 & $\mathrm{T}$ & 0.08 & $1.40(0.90-2.17)$ & 0.16 & 0.82 & $1.47(1.10-1.97)$ & 0.012 & 0.061 \\
\hline CD68 & rs9901675 & A & 0.07 & $0.57(0.38-0.84)$ & 0.009 & 0.026 & $0.72(0.55-0.93)$ & 0.021 & 0.063 \\
\hline \multirow[t]{2}{*}{$I G H$} & rs57767447 & $\mathrm{T}$ & 0.15 & $1.76(1.31-2.36)$ & 0.003 & 0.18 & $1.27(1.04-1.55)$ & 0.045 & 1.0 \\
\hline & rs10147756 & A & 0.11 & $0.56(0.40-0.79)$ & 0.006 & 0.40 & $0.82(0.65-1.04)$ & 0.14 & 1.0 \\
\hline$I G L$ & rs987710 & G & 0.29 & $0.70(0.55-0.89)$ & 0.011 & 1.0 & $0.91(0.77-1.07)$ & 0.30 & 1.0 \\
\hline
\end{tabular}

Table gives proportional increase (PI, or decrease if less than 1) in either total or large lesion count, along with 95\% confidence intervals and $p$ values. $p$ values in bold are considered statistically significant $(\mathrm{p} \leq 0.017)$.

* $\mathrm{p}$ values adjusted for Bonferroni correction.

der (table 4). Further, 3 variants (IL-6R rs114660934, MSR1 rs62489577 and CD14 rs778588) were significantly associated with both total and large lesion counts (table 4). An additional 9 variants in 8 inflammatory genes and 5 variants in 4 immune response genes were significantly associated with either total or large lesion count. Associations between total lesion count and TLR-4 rs10759930 and CD14 rs778588 remained significant after correcting for the number of variants tested per gene (table 4).

As a sensitivity analysis, we further adjusted analyses for presence of co-morbidities that might influence inflammatory and immune responses, including obesity, diabetes, hyperlipidemia, hypertension, auto-immune disorders, and cancer. None of these comorbidities were associated with large lesion count or history of $\mathrm{ICH}$ in any of the analyses, except obesity, which was significantly associated with fewer total lesions $(37 \%$ less lesions; $p=0.005$ ), as previously reported [1]. Ge- netic association results did not change whether we included these covariates in the model or not (data not shown).

\section{Association of the Whole Pathway and Sub-Pathways} with CCM1 Severity

Finally, to determine the impact of the whole inflammatory and immune response pathway, as well as the subpathways on CCM1 severity, we performed a set-based analysis. Taken together, the whole pathway was significantly associated with total lesion count $(\mathrm{p}=0.005)$; this association was driven notably by $I L-6 R$ rs 114660934 and CD14 rs778588 (above mentioned, associated with both total and large lesion counts), as well as TLR-4 rs10759930 and IGH rs57767447. Two sub-pathways (eicosanoid signaling and extracellular pattern recognition) were significantly associated with the total lesion count $(p=0.006)$ as well as immune response sub-pathway, which was nominally associated $(\mathrm{p}=0.033)$ (see online suppl. table 3 ). 


\section{Discussion}

We provide the first report of associations between common genetic variation and markers of CCM disease severity. Our results show that variants in the inflammatory and immune response pathways analyzed individually and as a set may be associated with disease severity in Hispanic CCM1-CHM subjects. Specifically, TGFBR2 rs9823731 was associated with all the 3 markers of CCM1 disease severity examined: history of $\mathrm{ICH}$, total lesion count, and large lesion count. Given the role of TGFBR2 as a receptor protein that binds TGF- $\beta$, this finding supports the implication of TGF- $\beta$ signaling in the onset and progression of CCM disease. Recently, Maddaluno et al. [10] reported that the inhibition of TGF- $\beta$ signaling reduces the number and size of lesions and vessel leakage in CCM1-deficient mice. Thus, TGFBR2 might be a key participant in the mechanism underlying CCM disease severity and phenotype variability. Further, $I L-6 R$ rs1 14660934 and CD14 rs778588 seem to be important genetic modifiers of CCM1 disease severity as those SNPs (1) were significantly associated with total and large lesion counts, and (2) drove the association of the whole pathway with total lesion count in addition to TLR-4 rs10759930, and IGH rs57767447.

Our findings extend previous studies implicating immune response in CCM pathogenesis. Shenkar et al. reported that immunoglobulin heavy and light chain genes were upregulated with up to 20 -fold change in human CCM lesions in comparison to brain AVM and normal superficial temporal arteries [4, 11]. Interestingly, we found that 3 common variants in the immunoglobulin heavy locus (IGH) and 5 common variants in the immunoglobulin lambda light chain locus (IGL) were associated with either ICH or total lesions. It is noteworthy that $I G H$ and IGL are both markers of B cells, and histology studies have shown the presence of $B$ cells within quiescent CCM lesions as well as within aggressive ones (characterized notably by new hemorrhage) [4-7].

Our findings also extend previous studies suggesting that inflammatory cytokine genes are involved in brain vascular disease pathogenesis. As similarly observed in brain AVM patients [14], we found that polymorphisms in $I L-1 R N$ were significantly associated with $\mathrm{ICH}$ in CCM1-CHM subjects. Further, we also reported associations with additional inflammatory cytokines and their receptors, notably, $I L-6 R$, and TGFBR2. Similarly, polymorphisms in $I L-6 R$ and TGFBR2 genes have been associated with other vascular diseases, such as abdominal aortic aneurysm [35, 36]. Multiple genetic polymorphisms in inflammatory cytokines have been reported to act as modi- fying factors in numerous diseases. For example, polymorphisms in TGFB1 modify the severity of pulmonary disease in patients with cystic fibrosis [37], while functional polymorphisms in $I L-4$ and $I L-10$ may predict evolution and functional outcome of ischemic stroke [38].

We also for the first time provide heritability estimates for the three markers of CCM1 disease severity using two different methods (SNP-based and family-based approaches). Similar heritability estimates were produced by both methods and the total lesion count phenotype had the highest heritability estimate (63-81\%), suggesting that this marker of CCM1 disease severity is the most likely to be affected by genetic modifiers, which can be discovered by association studies. However, the presence of relatedness in our sample might have led to an overestimation of heritability, as previously described [30-33]. Our estimate of heritability for ICH risk (20\%) is similar to that reported in non-CCM cohorts $(29 \%$ in unrelated subjects) [39], and suggests that ICH risk may be more strongly influenced by environmental factors than genetic effects.

A limitation of the current study was the relatively small sample size for association studies. In view of this limitation, we restricted the number of candidate genes; however, other genes in inflammatory and immune response pathways might be important to explore in future larger genetic studies. Nevertheless, we were able to detect a polymorphism (TGFBR2 rs9823731) consistently associated with all three markers of CCM1 disease severity tested. Additionally, this was a cross-sectional analysis of baseline findings and cannot directly address whether these genetic variants are associated with CCM1 disease progression. The BVMC study is continuing follow-up in the cohort, and it will be interesting to determine if these genetic variants predict risk of ICH or increase in lesion counts in longitudinal analysis. The main strength of the study is the unique population of well-characterized familial CCM1 subjects all sharing an identical genetic mutation, which allows for the evaluation of genotype-phenotype associations without confounding by CCM mutation type.

In conclusion, these results suggest that common genetic variation in inflammatory and immune response pathways may influence familial CCM1 disease severity, and warrant replication in other CCM cohorts and further investigation into the precise mechanism of how those pathways are involved. A better understanding of the natural history of the disease, including risk factors for disease severity and phenotype variability, is essential to improve knowledge of the mechanisms involved in CCM pathogenesis that may lead to new therapies. 


\section{Acknowledgments}

The authors would like to thank all the CCM1-CHM subjects who participated in this clinical research study. Recruitment efforts, DNA and patient records were provided by the Angioma Alliance's Patient Registry and DNA/Tissue Bank.

The Brain Vascular Malformation Consortium (BVMC) is supported by a grant from the National Institutes of Health (U54
NS065705), and is a part of the NIH Rare Disease Clinical Research Network, supported through a collaboration between the NIH Office of Rare Diseases Research at the National Center for Advancing Translational Science, and the National Institute of Neurological Disorders and Stroke (NINDS). HC was supported by a Postdoctoral Fellowship award from the American Heart Association (AHA 14POST20380213).

\section{References}

1 Choquet H, Nelson J, Pawlikowska L, McCulloch CE, Akers A, Baca B, Khan Y, Hart B, Morrison L, Kim H: Association of cardiovascular risk factors with disease severity in cerebral cavernous malformation type 1 subjects with the common Hispanic mutation. Cerebrovasc Dis 2014;37:57-63.

2 Denier C, Labauge P, Brunereau L, Cave-Riant F, Marchelli F, Arnoult M, Cecillon M, Maciazek J, Joutel A, Tournier-Lasserve E: Clinical features of cerebral cavernous malformations patients with KRIT1 mutations. Ann Neurol 2004;55:213-220.

- 3 Morrison L, Akers A: Cerebral cavernous malformation, familial; in Pagon RA, Bird TD, Dolan CR, Stephens K, Adam MP (eds): GeneReviews. Seattle, University of Washington, 2003. Available at http://www.genetests. org (updated May 31, 2011).

4 Shenkar R, Shi C, Check IJ, Lipton HL, Awad IA: Concepts and hypotheses: inflammatory hypothesis in the pathogenesis of cerebral cavernous malformations. Neurosurgery 2007;61:693-702.

-5 Shi C, Shenkar R, Batjer HH, Check IJ, Awad IA: Oligoclonal immune response in cerebral cavernous malformations. Laboratory investigation. J Neurosurg 2007;107:1023-1026.

6 Shi C, Shenkar R, Du H, Duckworth E, Raja $\mathrm{H}$, Batjer HH, Awad IA: Immune response in human cerebral cavernous malformations. Stroke 2009;40:1659-1665.

-7 Shi C, Shenkar R, Kinloch A, Henderson SG, Shaaya M, Chong AS, Clark MR, Awad IA: Immune complex formation and in situ B-cell clonal expansion in human cerebral cavernous malformations. J Neuroimmunol 2014; 272:67-75.

8 Vymazal J, Brooks RA, Baumgarner C, Tran V, Katz D, Bulte JW, Bauminger R, Di Chiro G: The relation between brain iron and NMR relaxation times: an in vitro study. Magn Reson Med 1996;35:56-61.

-9 Plummer NW, Gallione CJ, Srinivasan S, Zawistowski JS, Louis DN, Marchuk DA: Loss of p53 sensitizes mice with a mutation in $\mathrm{Ccm} 1$ (KRIT1) to development of cerebral vascular malformations. Am J Pathol 2004;165:15091518.

10 Maddaluno L, Rudini N, Cuttano R, Bravi L, Giampietro C, Corada M, Ferrarini L, Orsenigo F, Papa E, Boulday G, Tournier-Lasserve E,
Chapon F, Richichi C, Retta SF, Lampugnani MG, Dejana E: EndMT contributes to the onset and progression of cerebral cavernous malformations. Nature 2013;498:492-496.

-11 Shenkar R, Elliott JP, Diener K, Gault J, Hu LJ, Cohrs RJ, Phang T, Hunter L, Breeze RE, Awad IA: Differential gene expression in human cerebrovascular malformations. Neurosurgery 2003;52:465-478.

12 Achrol AS, Pawlikowska L, McCulloch CE, Poon KY, Ha C, Zaroff JG, Johnston SC, Lee C, Lawton MT, Sidney S, Marchuk DA, Kwok PY, Young WL: Tumor necrosis factor-alpha$238 \mathrm{G}>$ A promoter polymorphism is associated with increased risk of new hemorrhage in the natural course of patients with brain arteriovenous malformations. Stroke 2006;37:231-234.

13 Chen Y, Pawlikowska L, Yao JS, Shen F, Zhai W, Achrol AS, Lawton MT, Kwok PY, Yang GY, Young WL: Interleukin-6 involvement in brain arteriovenous malformations. Ann Neurol 2006;59:72-80.

14 Fontanella M, Rubino E, Crobeddu E, Gallone S, Gentile S, Garbossa D, Ducati A, Pinessi L, Rainero I: Brain arteriovenous malformations are associated with interleukin-1 cluster gene polymorphisms. Neurosurgery 2012;70:12-17.

$\checkmark 15$ Kim H, Hysi PG, Pawlikowska L, Poon A, Burchard EG, Zaroff JG, Sidney S, Ko NU, Achrol AS, Lawton MT, McCulloch CE, Kwok PY, Young WL: Common variants in interleukin-1-beta gene are associated with intracranial hemorrhage and susceptibility to brain arteriovenous malformation. Cerebrovasc Dis 2009;27:176-182.

16 Pawlikowska L, Tran MN, Achrol AS, McCulloch CE, Ha C, Lind DL, Hashimoto T, Zaroff J, Lawton MT, Marchuk DA, Kwok PY, Young WL: Polymorphisms in genes involved in inflammatory and angiogenic pathways and the risk of hemorrhagic presentation of brain arteriovenous malformations. Stroke 2004;35:2294-2300.

17 Slowik A, Borratynska A, Turaj W, Pera J, Dziedzic T, Wloch D, Szczudlik A, Betlej M, Krzyszkowski T, Czepko R: Interleukin 1beta$511 \mathrm{C} / \mathrm{T}$ polymorphism and risk of aneurysmal subarachnoid haemorrhage. J Neurol Neurosurg Psychiatry 2006;77:279-280.

18 Al-Shahi Salman R, Berg MJ, Morrison L, Awad IA: Hemorrhage from cerebral cavernous malformations of the brain: definition and reporting standards. Angioma Alliance Scientific Advisory Board. Stroke 2008;39: 3222-3230.

19 Hoffmann TJ, Zhan Y, Kvale MN, Hesselson SE, Gollub J, Iribarren C, Lu Y, Mei G, Purdy MM, Quesenberry C, Rowell S, Shapero MH, Smethurst D, Somkin CP, Van den Eeden SK, Walter L, Webster T, Whitmer RA, Finn A, Schaefer C, Kwok PY, Risch N: Design and coverage of high throughput genotyping arrays optimized for individuals of East Asian, African American, and Latino race/ethnicity using imputation and a novel hybrid SNP selection algorithm. Genomics 2011;98:422430.

20 Kim H, Marchuk DA, Pawlikowska L, Chen Y, Su H, Yang GY, Young WL: Genetic considerations relevant to intracranial hemorrhage and brain arteriovenous malformations. Acta Neurochir Suppl 2008;105:199206.

-21 Kaczorowski DJ, Mollen KP, Edmonds R, Billiar TR: Early events in the recognition of danger signals after tissue injury. J Leukoc Biol 2008;83:546-552.

22 Wang Y, Ge P, Zhu Y: TLR2 and TLR4 in the brain injury caused by cerebral ischemia and reperfusion. Mediators Inflamm 2013;2013: 124614.

23 Winters L, Winters T, Gorup D, Mitrecic D, Curlin M, Kriz J, Gajovic S: Expression analysis of genes involved in TLR2-related signaling pathway: inflammation and apoptosis after ischemic brain injury. Neuroscience 2013; 238:87-96.

24 Colaizzo D, Fofi L, Tiscia G, Guglielmi R, Cocomazzi N, Prencipe M, Margaglione M, Toni D: The COX-2 G/C -765 polymorphism may modulate the occurrence of cerebrovascular ischemia. Blood Coagul Fibrinolysis 2006;17: 93-96.

25 Liu LX, Zhou XY, Li CS, Liu LQ, Huang SY, Zhou SN: Selenoprotein S expression in the rat brain following focal cerebral ischemia. Neurol Sci 2013;34:1671-1678.

26 Alanne M, Kristiansson K, Auro K, Silander K, Kuulasmaa K, Peltonen L, Salomaa V, Perola M: Variation in the selenoprotein $S$ gene locus is associated with coronary heart disease and ischemic stroke in two independent Finnish cohorts. Hum Genet 2007;122: 355-365.
Inflammatory and Immune Response Polymorphisms and CCM1 Severity
Cerebrovasc Dis 2014;38:433-440 DOI: $10.1159 / 000369200$ 
27 Kazma R, Mefford JA, Cheng I, Plummer SJ, Levin AM, Rybicki BA, Casey G, Witte JS: Association of the innate immunity and inflammation pathway with advanced prostate cancer risk. PLoS One 2012;7:e51680.

28 Loza MJ, McCall CE, Li L, Isaacs WB, Xu J, Chang BL: Assembly of inflammation-related genes for pathway-focused genetic analysis. PLoS One 2007;2:e1035.

29 Yang J, Lee SH, Goddard ME, Visscher PM: GCTA: a tool for genome-wide complex trait analysis. Am J Hum Genet 2011;88:76-82.

-30 Yang J, Benyamin B, McEvoy BP, Gordon S, Henders AK, Nyholt DR, Madden PA, Heath AC, Martin NG, Montgomery GW, Goddard ME, Visscher PM: Common SNPs explain a large proportion of the heritability for human height. Nat Genet 2010;42:565-569.

- 31 Pasaniuc B, Zaitlen N, Lettre G, Chen GK, Tandon A, Kao WH, Ruczinski I, Fornage M, Siscovick DS, Zhu X, Larkin E, Lange LA, Cupples LA, Yang Q, Akylbekova EL, Musani SK, Divers J, Mychaleckyj J, Li M, Papanicolaou GJ, Millikan RC, Ambrosone CB, John EM, Bernstein L, Zheng W, Hu JJ, Ziegler RG, Nyante SJ, Bandera EV, Ingles SA, Press MF, Chanock SJ, Deming SL, Rodriguez-Gil JL, PalmerCD, BuxbaumS, Ekunwe L, Hirschhorn $\mathrm{JN}$, Henderson BE, Myers S, Haiman CA, Reich D, Patterson N, Wilson JG, Price AL: Enhanced statistical tests for GWAS in admixed populations: assessment using African Americans from CARe and a Breast Cancer Consortium. PLoS Genet 2011;7:e1001371.
2 So HC, Li M, Sham PC: Uncovering the total heritability explained by all true susceptibility variants in a genome-wide association study. Genet Epidemiol 2011;35:447-456.

-33 Kang HM, Sul JH, Service SK, Zaitlen NA, Kong SY, Freimer NB, Sabatti C, Eskin E: Variance component model to account for sample structure in genome-wide association studies. Nat Genet 2010;42:348-354.

34 Almasy L, Blangero J: Multipoint quantitative-trait linkage analysis in general pedigrees. Am J Hum Genet 1998;62:1198-1211.

35 Harrison SC, Smith AJ, Jones GT, Swerdlow DI, Rampuri R, Bown MJ, Folkersen L, Baas AF, de Borst GJ, Blankensteijn JD, Price JF, van der Graaf Y, McLachlan S, Agu O, Hofman A, Uitterlinden AG, Franco-Cereceda A, Ruigrok YM, van't Hof FN, Powell JT, van Rij AM, Casas JP, Eriksson P, Holmes MV, Asselbergs FW, Hingorani AD, Humphries SE: Interleukin-6 receptor pathways in abdominal aortic aneurysm. Eur Heart J 2013;34: 3707-3716.
36 Biros E, Walker PJ, Nataatmadja M, West M, Golledge J: Downregulation of transforming growth factor, beta receptor 2 and Notch signaling pathway in human abdominal aortic aneurysm. Atherosclerosis 2012;221:383-386.

37 Drumm ML, Konstan MW, Schluchter MD, Handler A, Pace R, Zou F, Zariwala M, Fargo D, Xu A, Dunn JM, Darrah RJ, Dorfman R, Sandford AJ, Corey M, Zielenski J, Durie P, Goddard K, Yankaskas JR, Wright FA, Knowles MR: Genetic modifiers of lung disease in cystic fibrosis. N Engl J Med 2005;353: 1443-1453.

38 Marousi S, Ellul J, Antonacopoulou A, Gogos C, Papathanasopoulos P, Karakantza M: Functional polymorphisms of interleukin 4 and interleukin 10 may predict evolution and functional outcome of an ischaemic stroke. Eur J Neurol 2011;18:637-643.

39 Devan WJ, Falcone GJ, Anderson CD, Jagiella JM, Schmidt H, Hansen BM, JimenezConde J, Giralt-Steinhauer E, Cuadrado-Godia E, Soriano C, Ayres AM, Schwab K, Kassis SB, Valant V, Pera J, Urbanik A, Viswanathan A, Rost NS, Goldstein JN, Freudenberger P, Stogerer EM, Norrving B, Tirschwell DL, Se$\lim$ M, Brown DL, Silliman SL, Worrall BB, Meschia JF, Kidwell CS, Montaner J, Fernandez-Cadenas I, Delgado P, Greenberg SM, Roquer J, Lindgren A, Slowik A, Schmidt R, Woo D, Rosand J, Biffi A: Heritability estimates identify a substantial genetic contribution to risk and outcome of intracerebral hemorrhage. Stroke 2013;44:1578-1583. 